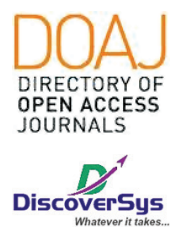

Published by DiscoverSys

\title{
Asosiasi sikap dan pengetahuan orang tua terhadap perilaku dalam menangani anak saat diare di Kecamatan Seririt, Kabupataen Buleleng, Bali tahun 2018
}

\author{
Putu Andrie Setiawan, ${ }^{1 *}$ Ryan, ${ }^{2,5}$ Derryl Komala Putra, ${ }^{2,5}$ Andy Halim, ${ }^{2,5}$ \\ Nelvina Ginting, ${ }^{3,5}$ Maria Pricilla Siboe, ${ }^{4,5}$ Dyah Kanya Wati ${ }^{6}$
}

\section{ABSTRACT}

Introduction: To date, diarrhea is still a global burden that implicate children especially in development country. Seririt, as a peripheral subdistrict in Buleleng regency, Bali face this problem also. The knowledge and the attitude of parents is really important to reduce morbidity and mortality of dehydration to be caused by diarea.

Objective: This research was aimed to knowing the association of parents knowledge and attitude to behaviour when facing diarrhea.

Method: Cross-sectional method with consecutive sampling method was used to answer the objective. This research has done in 2018 of
August at community health canter (Puskesmas) Seririt 1, Buleleng Regency, Bali Province. Collected data was analysed with SPSS version 17 for Windows.

Result: A statistically significant result was found between attitude and behaviour ( $\mathrm{p}=0,000 ; 95 \% \mathrm{Cl}=1,484-9,387)$. Contrary, insignificant result was found among attitude and parent behaviour when face diarrhea ( $\mathrm{p}=0,093 ; 95 \% \mathrm{Cl}=0,900-3,155)$.

Conclusion: Parrents knowledge associate to parent behaviour, in other hand attitude does not associate to parent behaviour.

Keyword: diarrhea, children, seririt, knowledge, attitude, parent

Cite This Article: Setiawan,P.A., Ryan, Putra, D.K., Halim, A., Ginting, N., Siboe, M.P., Wati, D.K. 2020. Asosiasi sikap dan pengetahuan orang tua terhadap perilaku dalam menangani anak saat diare di Kecamatan Seririt, Kabupataen Buleleng, Bali tahun 2018. Intisari Sains Medis 11(2): 786-790. D0I: 10.15562/ism.v11i2.748

\section{ABSTRAK}

${ }^{1}$ Program Studi Pendidikan Dokter, Fakultas Kedokteran, Universitas Udayana, Denpasar, Bali

${ }^{2}$ Fakultas Kedokteran, Universitas, Tarumanegara, Jakarta

${ }^{3}$ Fakultas Kedokteran, Universitas Sumateran Utara, Medan

${ }^{4}$ Fakultas Kedokteran, Universitas Kristen Krida Wacana, Jakarta ${ }^{5}$ Dokter Internship RSUD BulelengPuskesmas Seririt 1, Bali

${ }^{6}$ Departemen IImu Kesehatan Anak, Fakultas Kedokteran, Universitas Udayana/RSUP Sanglah, Denpasar, Bali

\section{*Korespondensi:}

Putu Andrie Setiawan, Program Studi Pendidikan Dokter, Fakultas Kedokteran, Universitas Udayana, Denpasar, Bali

putuandriesetiawan@unud.ac.id

Diterima: 24-04-2020

Disetujui: 10-07-2020

Diterbitkan: 01-08-2020
Pendahuluan: Diare saat ini masih merupakan permasalahan utama pada balita. Hal ini juga merupakan masalah yang diahadapi didaerah perifer utamanya di Kecamatan Seririt, Kabupaten Buleleng, Bali. Pengetahuan dan sikap orang tua saat menangani diare berperan untuk mengurangi kesakitan dan kematian utamanya akibat dehidrasi. Tujuan: Tujuan dari penelitian ini adalah untuk mencari tahu asosiasi pengetahuan dan sikap terhadap perilaku orang tua saat anak mengalami diare di Kecamatan Seririt, Kabupaten Buleleng, Bali.

Metode: Metode potong lintang dan consecutive sampling diterapkan pada penelitian ini. Penelitian dilaksanakan pada bulan Agustus 2018 di Puskesmas Seririt 1, Buleleng. Data yang sudah dikumpulkan dianalisis dan disajikan dalam tabel dan narasi menggunakan perangkat lunak SPSS 17 for Windows.

Hasil:Secara statistik terdapat perbedaan antara tingkat pengetahuan dengan perilaku $(p=0,000 ; \quad I K=1,484-9,387)$. Sedangkan, tidak didapatkan perbedaan antara sikap dan perilaku subjek sehari-hari $(p=0,093 ; \mid K=0,900-3,155)$.

Kesimpulan: Terdapat hubungan yang bermakna antara tingkat pengetahuan orang tua terhadap perilaku saat menghadapi anak dengan diare. Namun, hal ini berbanding terbalik dengan sikap orang tua yang dinyatakan tidak berhubungan secara statistik terhadap perilaku saat anak mengalami diare.

Kata Kunci: diare, anak, seririt, perilaku, sikap, orang tua

Cite Pasal Ini: Setiawan,P.A., Ryan, Putra, D.K., Halim, A., Ginting, N., Siboe, M.P., Wati, D.K. 2020. Asosiasi sikap dan pengetahuan orang tua terhadap perilaku dalam menangani anak saat diare di Kecamatan Seririt, Kabupataen Buleleng, Bali tahun 2018. Intisari Sains Medis 11(2): 786-790. DOI: 10.15562/ism.v11i2.748

\section{PENDAHULUAN}

Saat ini penyakit diare, masih merupakan masalah kesehatan utamanya pada bayi kurang dari lima tahun (Balita). Hai ini tidak hanya di jumpai pada di tingkat global, namun juga pada tingkat regional
Asia Tenggara maupun nasional. Tercatat, diare menyebabkan 16\% kematian, sedikit lebih rendah dibandingkan dengan pneumonia, sedangkan pada tingkat regional (negara berkembang), diare 
menyumbang sekitar $18 \%$ kematian balita dari 3.070 juta balita. ${ }^{1}$ Di Indonesia, diare menjadi penyebab utama kematian pada balita, yaitu 25,2\%, lebih tinggi dibanding pneumonia, $15,5 \%{ }^{2}$

Berdasarkan data diatas, pencegahan dan penanganan diare pada anak memerlukan keterlibatan keluarga teutama ibu. Keterlibatan ibu dalam penatalaksanaan diare sangat penting. Oleh karena itu pengetahuan yang baik pada ibu sangat diperlukan untuk membentuk perilaku yang baik dalam hal tatalaksana dan pencegahan diare. Selain itu keterjangkauan sarana pelayanan kesehatan oleh masyarakat, tingkat kegawatan penyakit, dan pengalaman pengobatan sebelumnya baik atas pengalaman sendiri maupun orang lain turut mempengaruhi individu dalam pengambilan keputusan untuk mengobati penyakit. Seorang ibu juga sebaiknya memiliki pengetahuan umum mengenai diare. Pengetahuan umum mulai dari apa yang dimaksud dari diare, penyebab diare, cara pencegahan diare hingga tatalaksana awal untuk pasien diare agar anak tidak jatuh kepada kondisi yang paling berbahaya, yaitu dehidrasi berat. ${ }^{2,3,4,5}$

Memberikan upaya dalam penatalaksanaan diare pada anak adalah hal yang harus ibu ketahui sejak dini. Tindakan yang dilakukan ibu selama anak mengalami diare sangat menentukan tingkat kesembuhan dan lamanya (durasi) penyakit tersebut. Beberapa penelitian yang pernah dilakukan bahwa pendidikan kesehatan atau pemberian informasi pengetahuan seputar diare pada ibu memberikan pengaruh yang signifikan terhadap peningkatan pengetahuan, keterampilan dan perilaku ibu dalam memberikan pencegahan dan penanganan anak diare. ${ }^{4}$

Tingkat pengetahuan orangtua merupakan salah satu faktor penentu keberhasilan tatalaksana diare pada anak. Melihat pentingnya pengetahuan orangtua seputar diare, maka dilakukan penelitian dengan tujuan untuk mengetahui asosiasi tingkat pengetahuan dan sikap orangtua dengan perilaku terhadap kasus diare pada anak di Kecamatan Seririt pada bulan agustus 2018 .

\section{METODE}

Penelitian ini merupakan penelitian potong lintang yang dilakukan pada orangtua anak yang datang berobat ke poliklinik anak Puskesmas Seririt 1 dan mengambil waktu pada bulan Agustus 2018 di Puskesmas Seririt 1, Buleleng, Bali.

Pemilihan besar sample sampel dilakukan dengan teknik consecutive sampling dan berdasarkan kriteria inklusi dan eksklusi yang ada. Kriteria inklusi: 1) orang tua dengan anak berusia 2 bulan hingga 12 tahun, 2) anak tidak memiliki riwayat sakit kronis seperti keganasan dan gangguan metabolik. Kriteria eksklusi: 1) orang tua yang menolak untuk mengisi kuisioner, 2) orang tua buta huruf (tidak dapat membaca dan menulis). Orang tua yang tidak mengisi kuisioner secara lengkap dianggap sebagai drop out.

Variabel bebas pada penelitian ini adalah pengetahuan dan sikap orang tua. Sedangkan variabel tergantung adalah perilaku otang tua tentang diare. Pengetahuan orang tua diukur melalui 10 pertanyaan pilihan ganda pada kuisioner. Pengetahuan ini dibagi dalam tiga kategori yaitu pengetahuan baik (lebih dari $80 \%$ nilai keseluruhan), cukup (antara 60\% - 79\% dari nilai keseluruhan), dan kurang (kurang dari 60\% nilai keseluruhan).

Sikap orang tua diukur berdasarkan sembilan buah pertanyaan yang berhubungan dengan diare. Pilihan jawaban tersebut dikategorikan menjadi sangat setuju (SS), setuju (S), tidak setuju (TS), dan sangat tidak setuju (STS). Untuk pertanyaan yang bersifat positif, jawaban sangat setuju (SS) diberikan nilai lima, jawaban setuju (S) diberikan nilai tiga, jawaban tidak setuju (TS) dan jawaban sangat tidak setuju (STS) diberikan nilai satu. Untuk pertanyaan negatif berlaku kebalikannya. ${ }^{7}$

Sikap dikategorikan menjadi sikap yang mendukung (favourable) bila nilai sikap lebih lebih besar dari rerata nilai sikap seluruh subjek dan sikap kurang mendukung (unfavourable) bila nilai sikap lebih kecil dari rerata nilai seluruh subjek. ${ }^{7}$

Usia orang tua dihitung dalam tahun sesuai dengan kartu tanda penduduk. Jenis kelamin orang tua yang dicatat adalah jenis kelamin orang tua yang mengisi kuisioner secara langsung dikategorikan dengan laki-laki atau perempuan. Pendidikan terakhir orang tua didapat berdasarkan kuisioner dan di klasifikasikan menjadi tidak sekolah, pendidikan sekolah dasar, pendidikan sekolah menengah pertama, pendidikan sekolah menengah atas, dan perguruan tinggi. Pekerjaan orang tua di dapat berdasarkan kuisioner dan diklasifikasikan menjadi. Jumlah anak didapatkan berdasarkan kuisioner, merupakan jumlah anak yang saat ini sedang ditanggung baik anak kandung maupun tidak.

Data yang terkumpul dianalisis dan disajikan dalam bentuk tabel dan narasi menggunakan perangkat lunak SPSS 17 for Windows. Data dianalisis secara univariat untuk melihat gambaran distribusi data secara deskriptif.

\section{HASIL}

Setelah diterapkan kriteria inklusi serta eksklusi terhadap variabel penelitian didapatkan jumlah 61 subjek dan dari 61 subjek terdapat 10 subjek yang masuk kriteria drop out karena menolak mengisi 
Tabel 1 Karakteristik Orang Tua

\begin{tabular}{|c|c|c|}
\hline No & Karakteristik & $\mathbf{n}$ \\
\hline \multirow[t]{3}{*}{1.} & Jenis kelamin, n (\%) & \\
\hline & Laki-Laki & $21(42,0 \%)$ \\
\hline & Perempuan & $29(58,0 \%)$ \\
\hline 2. & Usia (tahun), rerata (SD) & $32(7,08)$ \\
\hline 3 & Jumlah anak, rerata (SD) & $2,06(0,99)$ \\
\hline 4 & Usia anak termuda (bulan), Mean (SD) & $41,02(39,36)$ \\
\hline \multirow[t]{9}{*}{5} & Asal, n (\%) & \\
\hline & Pengastulan & $8(16,0 \%)$ \\
\hline & Patemon & $9(18,0 \%)$ \\
\hline & Lokapaksa & $11(22,0 \%)$ \\
\hline & Tangguwisia & $2(4,0 \%)$ \\
\hline & Sulanyah & $1(2,0 \%)$ \\
\hline & Joanyar & $1(2,0 \%)$ \\
\hline & Banjar & $1(2,0 \%)$ \\
\hline & Seririt & $17(34,0 \%)$ \\
\hline \multirow[t]{5}{*}{6} & Pendidikan, n (\%) & \\
\hline & SD & $8(16,0 \%)$ \\
\hline & SMP & $16(32,0 \%)$ \\
\hline & SMA & $25(50,0 \%)$ \\
\hline & PT & $1(2,0 \%)$ \\
\hline \multirow[t]{4}{*}{7.} & Pekerjaan, n (\%) & \\
\hline & IRT & $16(32,0 \%)$ \\
\hline & Wirausaha & $26(52,0 \%)$ \\
\hline & Pegawai & $8(16,0 \%)$ \\
\hline
\end{tabular}

Tabel 2 Karakteristik Orang Tua berdasarkan Pengetahuan, sikap, dan Perilaku

\begin{tabular}{lcc}
\hline Variabel & Jumlah & $\%$ \\
\hline $\begin{array}{l}\text { Pengetahuan } \\
\text { • Baik }\end{array}$ & \\
• cukup & 10 & $20 \%$ \\
• Kurang & 18 & $36 \%$ \\
Perilaku & 22 & $44 \%$ \\
- Baik & & \\
- Kurang baik & 23 & $46 \%$ \\
Sikap & 27 & $54 \%$ \\
- Favourable & & \\
- Unfavourable & 24 & $48 \%$ \\
\hline
\end{tabular}

kuisioner dan satu orang tidak mengisi kuisioner secara lengkap. Total terdapat 50 subjek yang di masukan dalam penelitian yang terdiri dari 21 $(42,0 \%)$ laki-laki dengan rerata (SD) usia $32(7,08)$ tahun. Seluruh subjek rata-rata memiliki 2 orang anak dengan rata-rata (SD) usia anak termuda yaitu 41,02 $(39,36)$ bulan. Berdasarkan tempat tinggal pasien, seluruh pasien berasal dari kecamatan seririt dengan jumlah terbanyak dari desa seririt sebanyak 17 subjek (34\%) dengan pendidikan terbanyak yaitu tamatan SMA sebanyak 50\% subjek dan pekerjaan terbanyak didominasi oleh wirausaha 52\% (Tabel 1).

Berdasarkan tingkat pengetahuan, didapatkan lebih banyak subjek dengan tingkat pengetahuan kurang dengan nilai kurang dari $60 \%$ yaitu sebanyak 22 orang (44\%). Dari segi perilaku juga didapatkan bahwa sebanyak 27orang (54\%) berperilaku dibawah nilai rata-rata keseluruhan subjek. Dan dari segi sikap didapatkan 26 subjek memiliki nilai dibawah rata-rata keseluruhan subjek (Tabel 2).

Setelah dianalisis menggunakan tabel silang untuk mendapatkan hubungan antar variabel didapatkan bahwa terdapat perbedaan yang bermakna secara statistik antara tingkat pengetahuan dengan perilaku ( $\mathrm{p}=0,000$; $\mathrm{IK}=1,484-9,387)$. Sedangkan, tidak didapatkan perbedaan antara sikap dan perilaku subjek sehari-hari $(\mathrm{p}=0,093$; $\mathrm{IK}=0,900-3,155)$ (Tabel 3).

\section{DISKUSI}

Saat ini diare masih menjadi salah satu masalah kesehatan masyarakat di negara berkembang termasuk Indonesia. Di Indonesia sendiri, diare merupakan salah satu penyebab tingginya angka kesakitan dan angka kematian pada anak, terutama dibawah usia 5 tahun. ${ }^{2}$ Berdasarkan hasil Riskesdas 2007 diperoleh bahwa diare merupakan penyebab kematian bayi yang terbanyak yaitu $42 \%$, dibandingkan pneumonia (24\%). ${ }^{2}$ Berdasarkan Riskesdas tahun 2013, Aceh, Papua, Sulawesi Selatan, Banten, dan DKI Jakarta menjadi provinsi dengan kasus diare terbanyak. Bali sendiri memiliki periode prevalence $(3,6 \%)$ yang lebih baik dibanding ratarata periode prevalance nasional $(4,5 \%){ }^{6}$ Namun hal tersebut tidak serta merta menjadikan Bali daerah yang bebas diare pada anak, oleh sebab itu evaluasi harus sering dilakukan. Berdasarkan penelitian sebelumnya, pengobatan diare yang dilakukan oleh orang tua terhadap anaknya dipengaruhi oleh tingkat pengetahuan serta sikap orang tua. Pengetahuan dan sikap orang tua diharapkan mempengaruhi perilak nyata terhadap pencegahan maupun penanganan anak saat diare. ${ }^{6}$

Pada penelitian ini didapatkan mayoritas orangtua memiliki pengetahuan yang cukup hingga baik (56\%) hal ini sejalan denganpenelitian yang dilakukan Arini (2018) di RSCM Jakarta yang mendapatkan bahwa 99\% orangtua memiliki tingkat pengetahuan yang baik. ${ }^{7}$ Supono dkk di Bekasi juga mendapatkan bahwa 59,4\% ibu memiliki tingkat pengetahuan yang baik. ${ }^{8} \mathrm{Hal}$ ini kemungkinan diakibatkan oleh mayoritas subjek penelitian 
Tabel 3 Asosiasi Pengetahuan dan Sikap Orangtua Terhadap Perilaku Saat Menghadapi Diare pada Anak

\begin{tabular}{lccc}
\hline \multirow{2}{*}{ Variabel } & \multicolumn{2}{c}{ Perilaku } & \multirow{2}{*}{ p (IK) } \\
\cline { 2 - 3 } Pengetahuan & Baik & Kurang & \\
• Baik-Cukup & $19(67,9 \%)$ & $9(32,1 \%)$ & $0,000(1,484-9,387)$ \\
• Kurang & $4(18,2 \%)$ & $18(81,8 \%)$ & \\
Sikap & & & \\
- Favourable & $14(58,3 \%)$ & $10(41,7 \%)$ & $0,093(0,900-3,155)$ \\
- Unfavourabe & $9(34,6 \%)$ & $17(65,4 \%)$ & \\
\hline
\end{tabular}

( $>50 \%)$ memiliki pendidikan diatas sekolah menengah atas (SMA) dan mayoritas subjek juga bertempat tinggal di seririt yang merupakan pusat kota kecamatan yang memiliki akses pengetahuan dan informasi yang lebih banyak dibandingkan daerah domisili lain.

Berbeda dengan penelitian Arini (2018) yang mendapatkan bahwa sikap subjek cenderung positif terhadap penyakit diare, pada penelitian ini didapatkan sebaliknya dimana $52 \%$ subjek cenderung mengganggap diare merupakan penyakit yang kurang serius dan tidak perlu diwaspadai. ${ }^{7}$ Namun hal ini sejalan dengan penelitian Supono dkk yang melaporkan bahwa 45,1\% subjek yang beranggapan diare merupakan penyakit berbahaya. ${ }^{7}$ Menurut analisis dari Arini, perbedaan ini kemungkinan disebabkan oleh peran variabel perancu, seperti pengetahuan, pengalaman kontak dengan diare dan kepercayaan subjek. ${ }^{8}$ Menurut teori perubahan perilaku, dikatakan bahwa sikap seseorang terhadap masalah tertentu dipengaruhi oleh beberapa hal, seperti diantaranya, pengalaman pribadi, pengaruh orang yang dianggap penting, kebudayaan, media massa, lembaga pendidikan, lembaga agama, dan faktor emosional. Perbedaan karakter yang disebabkan oleh faktor geografis diduga juga sebagai penyebab perbedaan hasil yang didapatkan Arini dan penelitian ini. ${ }^{9,10}$

Dari segi perilaku, pada penelitian ini ditemukan lebih banyak subjek yang belum melakukan penanganan diare yang sesuai. Berbeda dengan penelitian yang dilakukan Amare Dkk yang mendapatkan bahwa perilaku baik lebih banyak dibanding yang berperilaku kurang baik $(54,1 \%)$. Dari penelitian ini didapatkan bahwa subjek dengan pendidikan menengah kebawah cenderung untuk berperilaku kurang baik $(55,5 \%)$ dibandingkan dengan subjek yang berpendidikan lebih tinggi. Dari segi pekerjaan juga dipatkan bahwa subjek yang bekerja sebagai pegawai cenderung berperilaku kurang baik dibanding pekerjaan lainnya hal ini kemungkinan disebabkan karena waktu yang dimiliki dirumah untuk merawat anaknya lebih sedikit dibanding ibu rumah tangga dan wirausaha. ${ }^{11}$

Berdasarkan analisis bivariate untuk mencari hubungan antara pengetahuan dan perilaku orang tua terhadap anak yang diare, didapatkan hubungan yang signifikan secara statistik $(\mathrm{p}=0,000$; $\mathrm{IK}=1,484-9,387)$ namun tidak pada populasi karena interval kepercayaan yang lebar. Secara statistik semakin tinggi pengetahuan subjek mengenai diare semakin baik perilaku terhadap anak dan begitu sebaliknya. Sedangkan, tidak ada hubungan secara statistik antara sikap dan perilaku subjek terhadap diare pada anak ( $\mathrm{p}=0,093$; $\mathrm{IK}=0,900-3,155)$. Hal ini berbeda dengan yang didapatkan oleh Arini dimana tidak didapatkan asosiasi antara pengetahuan dan sikap terhadap perilaku. Faktor geografis dan jumlah sampel diduga sebagai penyebab perbedaan ini. ${ }^{7}$

Pada penelitian yang dilakukan di Seririt untuk mengetahui asosiasi tingkat pengetahuan dan sikap orangtua dengan perilaku terhadap kasus diare pada anak di Puskesmas Seririt I pada bulan agustus 2018 didapatkan bahwa terdapat hubungan yang bermakna antara tingkat pengetahuan orang tua terhadap perilaku saat menghadapi anak dengan diare. Namun, hal ini berbanding terbalik dengan sikap orang tua yang dinyatakan tidak berhubungan secara statistik terhadap perilaku saat anak mengalami diare. Untuk penelitian lebih lanjut diharapkan jumlah sampel penelitian yang lebih besar untuk mendapatkan data yang lebih konkret. Proses penyuluhan mengenai diare pada orang tua di wilayah kerja Puskesmas Seririt 1 sudah baik terbukti dengan tingkat pengetahuan orang tua tentang diare yang tergolong baik dibandingkan rata-rata orang tua yang memeriksakan anaknya di Puskesmas Seririt 1. Pengetahuan orang tua yang baik juga cenderung berperilaku baik Namun masih ada orang tua yang tingkat pengetahuannya kurang baik dan perlu pemaparan lebih sering mengenai apa itu diare dan bagaimana pencegahannya.

\section{KONFLIK KEPENTINGAN}

Tidak terdapat konflik kepentingan dalam pada saat penelitian dan penyusunan naskah untuk dipublikasikan.

\section{PENDANAAN}

Penelitian dan penulisan naskah didanai oleh penulis. 


\section{ETIKA PENELITIAN}

Penelitian ini telah mendapatkan persetujuan untuk dilakukan oleh komite etika dan penelitian Pemerintah Kabupaten Buleleng dan Puskesmas Seririt 1, Kecamatan Seirit, Kabupaten Buleleng, Bali.

\section{KONTRIBUSI PENULIS}

Seluruh penulis berkontribusi sama terhadap penelian dan naskah yang dihasilkan.

\section{DAFTAR PUSTAKA}

1. Radlovic, Nedeljko \& Lekovic, Zoran \& Vuletić, Biljana \& Radlović, Vladimir \& Simic, Dusica. (2015). Acute Diarrhea in Children. Srpski arhiv za celokupno lekarstvo. 143. 755-762. 10.2298/SARH1512755R.

2. Badan penelitian dan pengembangan Kesehatan, Departemen Kesehatan RI.Riset Kesehatan Dasar (Riskesdas). Jakarta:2007.

3. Kementrian Kesehatan RI. Buku Saku Lintas Diare untuk Petugas Kesehatan, Kementerian Kesehatan RI. Jakarta: 2010.

4. Adisasmito W., 2007. Faktor Resiko Diare Pada Bayi dan Balita di Indonesia. Systemic Review Penelitian Akademik Bidang Kesehatan Masyarakat, Universitas Indonesia.
5. Suraatmaja S, 2010. Kapita Selekta Gastroenterologi Anak. Jakarta: Sagung Seto.

6. Badan Penelitian dan Pengembangan Kesehatan. Riset Kesehatan Dasar 2013. Jakarta: Kementerian Kesehatan RI; 2013.h. 72-6.

7. Hapsari, A. and Gunardi, H. (2018). Hubungan Pengetahuan dan Sikap dengan Perilaku Orangtua tentang Diare pada Balita di RSCM Kiara. Jakarta: Sari Pediatri. http://dx.doi.org/10.14238/sp19.6.2018.316-20

8. Supono, J. Faktor prediksi persepsi ibu tentang diare pada balita. Jurnal Kesehatan Masyarakat Nasional 2008;2: 179-85.

9. Davis, Rachel \& Campbell, Rona \& Hildon, Zoe \& Hobbs, Lorna \& Michie, Susan. (2014). Theories of behaviour and behaviour change across the social and behavioural sciences: a scoping review. Health psychology review. 9. 1-22. 10.1080/17437199.2014.941722.

10. Neef, Nancy \& Peterson, Stephanie. (2003). Behavior Theory and Philosophy. 10.1007/978-1-4757-4590-0_20.

11. Amare D, Dereje B, Kassie B, Ayele A, dkk. Maternal knowledge and practice towards diarrhoea management in under five children in Fenote Selam Town, West Gojjam Zone, Amhara Regional State, Northwest Ethiopia. J Infect Dis Ther 2014;2:6-16.

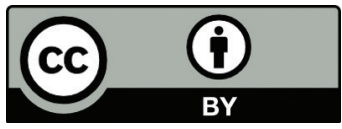

This work is licensed under a Creative Commons Attribution 